\title{
PERSPEKTIF EKONOMI SYARIAH DI INDONESIA TENTANG RIBA, BUNGA BANK, DAN BAGI HASIL
}

\author{
Hisam Ahyani \\ Mahasiswa Program Doktoral Hukum Islam, UIN Sunan Gunung Djati Bandung, \\ hisamahyani@gmail.com
}

\begin{abstract}
This study aims to reveal the existence of community conceptions related to profit sharing (Sharia economics), usury, bank interest (conventional), in terms of Islamic economics, where these 3 (three) things are unique and interesting if we discuss in the era of disruption like today. The era of discipline 4.0 as it is now is very interesting and unique regarding the study of the prohibition of usury in Indonesia, what is unique is the Khilafiyah which is the basis for especially Muslims (sharia economic actors), the need for tolerance between the views of schools of thought in Indonesia regarding this usury in sharia economics (muamalah) in order to benefit together in this world and in the hereafter. This study uses the Library Research Method and collects data obtained by means of literature studies from books and journals relevant to studies on usury and bank interest (conventional), profit sharing (Islamic economics). Related to research on the perspective of Islamic economics in the current era of disruption, especially in Indonesia regarding usury, and bank interest (conventional), as well as profit sharing (Islamic economics) so far no one has examined it. from a sharia economic point of view related to profit sharing, usury and also bank interest have a good impact on the economy in Indonesia, where the profit sharing system can help people in terms of social resilience, and overcome social inequalities (making tahsin / benefit of the ummah). The public, in their view of usury, bank interest and profit sharing within the Islamic economic community, requires tolerance in punishing these three things, as a result there is no "bank interest" in the Shariāh economic sphere (replaced by profit sharing), which is currently being shared. this outcome (Islamic economics) is seen as an effective measure to prevent conflict in gaps in dealing with impacts on the Economy and Social Affairs, as well as resilience to the community environment.
\end{abstract}

Keywords: Shariāh economics, rìibā, bank interest and profit sharing

\begin{abstract}
ABSTRAK
Penelitian ini bertujuan guna mengungkap adanya konsepsi masyarakat terkait bagi hasil (ekonomi Syariah), riba, bunga bank (konvensional), ditinjau dari ekonomi syariah, dimana 3 (tiga) hal ini unik dan menarik jika kita bahas di era disrupsi seperti sekarang ini disurpsi 4.0
\end{abstract}


seperti sekarang sangat menarik dan unik terkait kajian haramnya riba di Indonesia, uniknya adalah Khilafiyah yang menjadi sandaran khususnya umat muslim (pelaku ekonomi syariah), perlunya toleransi antar pandangan madzhab di Indonesia terkait riba ini dalam ekonomi syariah (muamalah) guna menjadikan kemaslahatan bersama di dunia dan di akhirat kelak. Penelitian ini menggunakan metode Library Research dan mengumpulkan data yang diperoleh dengan cara Studi Kepustakaan dari Buku-buku dan jurnal yang relevan dengan kajian tentang Riba dan bunga bank (konvensional), bagi hasil (ekonomi Syariah). Penelitian perspektif ekonomi syariāh di era disrupsi seperti sekarang ini khusunya di Indonesia tentang riba, dan bunga bank (konvensioanal), dan juga bagi hasil (ekonomi Syariah) sejauh ini belum ada yang meneliti. Hasil penemuan, dari sudut pandang ekonomi syariah terkait bagi hasil, riba dan juga bunga bank memberi dampak yang baik bagi perekonomian di Indonesia, dimana sistem bagi hasil dapat membantu masyarakat dalam hal ketahanan sosial, serta mengatasi kesenjangan sosial (menjadikan tahsin/kemaslahatan ummat).Kalangan Masyarakat dalam cara pandangannya terkait riba, bunga bank dan juga bagi hasil ini dalam lingkup masyarakat ekonomi syariah memerlukan toleransi dalam menghukumi ketiga hal tersebut, alhasil "bunga bank"dalam lingkup ekonomi Syariāh tidak ada (diganti dengan bagi hasil), dimana dewasa ini bagi hasil ini (ekonomi Syariah) dipandang sebagai langkah efektif dalam rangka mencegah konflik kesenjangan dalam menangani dampak pada Ekonomi dan Sosial, serta ketahanan pada lingkungan masyarakat.

Kata Kunci : Ekonomi syariāh, Riba, bagi hasil dan bunga bank, Disrupsi

\section{PENDAHULUAN}

Pandangan Umer chapra seorang ekonom muslim abad kontemporer terkait riba sebagaimana dikutip oleh (Zaelani 2012) bahwa risetnya ditemukan bahwa masih terdapat ditemukan adanya perbedaan pandanngan dengan hukum dari pada "Ŕibā” itu sendiri, sehingga Pembangunan nasional terkait bidang hukum merupakan tugas bersama warga bangsa Indonesia dimana kita dituntut oleh semua pihak dalam mendukungnya. Hal ini di karenakan dengan adanya "konsep-konsep hukum" yang ada di Indonesia ini masih banyak diwarisi dari hukum kolonial belanda, dan masyarakat seiring berjalannya waktu silih berganti terus menerus mengalami perkembangan yang signifikan. Hal inilah yang mengharuskan pengkajian secara continue apakah hukum yang ada sekarang ini masih relevan dengan kondisi era atau zaman dan masyarakat sekarang ini (era disrupsi). Pandangan Masyarakat tidak hanya mengedepankan kepatuhan saja, yang "tidak patuhnya masyarakat" pada suatu hukum di Indonesia disebabkan oleh masyarakat itu sendiri (hukum sudah ada, maysarkat memilih), dimana masyarakat menganggap bahwa hukum yang berlaku di Indonesia ini sudah tidak memenuhi kebutuhan masyarakat. Salah satu contohnya adalah bahwa banyak ulamā yang berpendapat bahwa "bunga 
bank"adalah "Ŕibā" dan "Ŕibā" adalah hāŕam (ekonomi syariah). Pertanyaannya adalah Rakyat Indonesia yang bagaimana yang baik?, Umat muslim yang bagaimana yang baik, Pendapat Ulama yang bagaimana yang baik?. Ini yang menjadikan tumpang tindih dalam memahami hukum. Namun tidak demikian halnya dengan sikap masyarakat. Banyak kalangan ulamā dan bahkan dari hasil fatwa yang dicanangkan oleh MUI (Majelis Ulama Indonesia) yang menegaskan bahwa "bunga bank" adalah "Ŕibā" dan hal ini tekait "Ŕỉbā" adalah (harām hukumnya) namun fakta di lapangan sering kita jumpai (umat ìslam di Indonesia khusunya) yang banyak menggunakan bank konvensional sebagai tempat bertransaksi walau sudah dijelaskan bahwa "bunga bank"konvensional itu "Ŕibā" dan "Ŕỉbā" itu harām. Model dari pada Ekonomi Syariāh yang ada di Era Revolusi Industri 4.0 (era disrupsi) sekarang ini yang dibangun atas dasar fillosofi religiusitas, serta institusi yang berkeādìlan dan juga instrumen guna menjuju kepada kemaslahatan ummat bersama sebagaimana disinggung dalam Al-Quran surat al-takātsur ayat 1 s.d 2 yang artinya "Bermegah-megahan telah menjadikan lupa (lalai) kamu sekaliān, hingga (kamu sekalian umat manusia) masuk dalam kubur”.

Lebih lanjut riset oleh (Ghofur 2016) bahwa riba menjadi dasar utama pelarangan dalam al-qur'an, dengan riba menjadikan ketidaksemimbangan dalam ekonomi di Indonesia. Riset lainnya oleh (Syarif 2011) bahwa berbeda dengan mufassir yang memberikan konsep pada riba merupakan pemberian seseorang kepada orang lain dengan tujuan mendapat ridha alloh swt (artinya riba dengan tujuan demikian hanya pada imbalan sementara, artinya tidak sampai pada konsepsi menolong sampai di hari akhirat kelak, dengan demikian konsepsi riba (ekonomi syariah) dengan riba (ekonomi konvensioanal) jelas berbeda hasilnya, alhasil para mufassir berbeda pendapat inilah penyebabnya.

Dalam Tāfsir ringkas terkait Riba Bunga Bank, dan juga bagi hasil yang dicanangkan oleh kementerian Agama (Kemenag), terdpat dalam (Al-Quran Ayat (1) surat Al-Tākātsur) ini dijelaskan bahwa Setiap manusia (baik muslim maupun non-muslim), telah "bermegahmegahan" dalam hal (harta, dan keturunan), serta menjadi pengikut-nya "Syaitān" yang telah menjadikan lupa dari berdzikir dan mengingat sang pencipta (dari ketaqwaān kepada Allāh Swt) serta mempersiapkan diri dalam menuju hari kiamat (hari akhir) kelak. Dalam Prespektif Alqurān sendiri mengenai pembahasan masalah/pandangan "hukum "Ŕibā" sudah dijelaskan dengan tegas, yaitu yang pertama disinggung pada al-Qur'ān Surat Al-Rum ayat 39 yang artinya "Dan suatu Ri yang telah kamu perbuat/lakukan supaya menambah harta tersebut bagi semua 
manusia (di dunia saja), maka Riba itu tidak-lah menambah pahala disisi Allāh Swt (di akhirat kelak). Dan apa yang sudah kamu berikan (zakāt) yang kamu maksudkan/berikan kepada sesama manusia adalah tujuan utama-nya mencari keridhaān Allāh Swt semata (pahala di akhirat), maka dari itu orang yang berbuat (zakat bukan beruat riba) demikian itu termasuk arang-orang yang melipatgandakan pahalanya (akhirat)".

Selanjutnya yang Kedua, terkait Ŕỉā̄”, yang disinggung dalam ayat al-Qur'ān Surat Alnisā' ayat 161 yang artinya "Dan karena mereka itu-lah telah mengambil "Ŕìbā", padahal mereka telah di larang untuk mengambilnya (hajjiyyat) dan karena mereka memakan harta orang dengan jalan yang bātil (salah) karena kebutuhan. Maka akan kami sediakan untuk orangorang kafir (riba untuk mengharap laba semata) itu berupa siksaan yang pedih".Ketiga terkait Ŕìbā” yang dijelaskan dalam al-Quran yaitu ayat yang ada pada surat Ali Imrān ayat 130 yang artinya: "Hai orang-orang yang beriman, janganlah kamu berbuat (memakan) "Ŕibā" dengan berlipat ganda (untuk kepentingan duniawi saja) dan bertaqwālah kamu kepada Allāh supaya kamu mendapat kemenangan (di dunia dan di akhirat)." Ayat tentang "Ŕìbā" yang terakhir yaitu terdapat pada al-Qur'ān Surat Al-bāqarāh ayat 275 yang artinya "Orang yang suka berbuat (memakan) "Ŕibā" itu tidak dapat berdiri, tetapi akan berdiri seperti orang yang kerasukan/kemasukan syaitān karena riba itu menimbulakn yakit jiwa (egoisme yang tinggi). Dan jika kamu berkenan/mau bertaubat (dari pengambilan/berbuat "Ŕibā”), maka bagimu hartamu, kamu tidak akan menganiaya dan tidak pula dianiaya”. Dengan memahami dari Asbābun Nùzùl (sebab-sebab turunnya Ayat-ayat) tentang ribā sangat penting sekali, hal ini disebabkan "ketetapan Al-qurān" hanya dapat kita pahami melalui sains/pengetahuan mengenai kondisi dan situasi sebab turunnya ayat al-quran tersebut. Jika di ikuti pendapat para ahli tāfsir (mufassir) dan riwayāt-riwayāt mereka tentang sebab-sebab turunnya ayat-ayat (riba) ini maka mayoritas mereka dapat diketahui bahwa bangsa Arāb Jahiliyah (dahulu) biasa melakukan/berbuat transaksi ribā, khususnya oleh kalangan orang kaya. Memang sudah terjadi transaksi produktif (inovatif) namun secara individual mereka memiliki eogisme yang tinggi seperti halnya yang terjadi pada bāni Tsāqif. Sudah sewajarnya jika orang kaya dengan sengaja memanfaatkan kesempatan bagi orang miskin yang hendak melakukan atau (menjebak) kepada perbuatan Ribā. Dengan demikian yang menjadi alasan/ Illat Hukumnya dari diharāmkan-nya ribā adalah karena ada unsur penindasan terhadap orang lain. 
Riset senada yang dicanangkan oleh (Aravik, Hamzani, and Khasanah 2021) bahwa konsepsi pemikiran ekonomi syariah terkait riba ini selalu menjadi menarik perhatian karena selalu mengalami kemajuan zaman (era disrupsi) semisal dengan konsepsi pemikiran yang bersifat kontemperorer dengan doktrin yang modern dengan menawarkan sistem ekonomi kapitalis dan juga ekonomi sosialita. Dimana di negara pakistan yang notabene termasuk negara islam, dengan kontribusi besarnya terhadap perokonomian negaranya adalah zakat, namun penggunaanya belum cukup efisien. Begitupun pendapat (Yulianti 2016) bahwa Bahwa riba adalah cara pengambilan keuntungan yang salah artinya (bertentangan dengan transaksi dalam islam) dari zaman romawi dan yunani kuno serta zaman jahiliyah, dan riba sendiri dilarang dalam ajaran islam dan kristen hal ini dikarenakan mengakibatkan dampak negatif dalam sosial masyarakat dan perekonomian menjadi tidak stabil karena riba ini.

Dengan demikian dari latar belakang yang begitu ganas akan adanya riba, maka ekonomi syariah dengan konsepsi bagi hasil menawarkan sebuah trobosan baru yang lebih baik, sehingga permasalahan ini segera ditemukan solusi yang berarti. Sehingga dalam penelitian ini penulis akan mengkaji permasalahan terkait Bagaimana Pandangan Ekonomi Syariāh di Indonesia terkait (“Ŕibā), (Bunga Bank), dan (“bagi hasil”)?; kedua, Bagaimana perbandingan antara Pandangan Ekonomi Syariāh di Indonesia terkait ("Ŕibā atau bunga bank) (ekonomi konvensional) dengan sistem bagi hasil (ekonomi syariah)?; ketiga, dampak apa saja dari (riba, bunga bank) dan bagi hasil tersebut terhadap Perekonomian Negara serta solusi dalam menghadapi ganasnya riba di Indonesia ?. Adapun tujuan penelitian ini adalah untuk mengetahui sudut Pandangan Ekonomi Syariāh di Indonesia terkait ("Ŕỉbā), (Bunga Bank), dan ("bagi hasil"); dan untuk mengetahui "perbandingan Pandangan" (Ekonomi Syariāh) di Indonesia terkait ("Ŕibā atau bunga bank) (ekonomi konvensional) dengan sistem bagi hasil (ekonomi syariah); ketiga, untuk mengetahui dampak apa saja dari (riba, bunga bank) dan bagi hasil tersebut terhadap Perekonomian Negara serta mengetahui solusi dalam menghadapi ganasnya riba di Indonesia.

\section{LITERATUR REVIEW}

\section{Riba}

Riset dalam hal pembahasan riba sebagaimana pendapat (Rasyid 2021) dalam bukunya berjudul "bunga bank adalah riba" beliau menjelaskan bahwa secara finansial sudah tidak ada 
tawar menawar lagi terkait ganasnya riba ini. Ironinya di Indonesia terkait riba ini malah justru menjadi makanan harian dimana riset terbaru oleh (Arif and Ashari 2021) bahwa penekakan riba dimasukan pada pembiayaan permodalan bagi nelayan kabupaten takalar, hal ini menyebabkan rendahnya pemasukan bagi para nelayan tersebut. Artinya riba yang dilakukan berdampak pada sektor permodalan. Selain itu Pandangan Ekonomi Syariāh di Indonesia terkait "Ŕìbā" disisi para pakar dan juga beberapa ahli hukum (Nasional) mempunyai anggapan bahwa riba merupakan musuh utama dalam perekonomian di Indonesia dikarenakan dampaknya yang sangat ganas, hal ini sebagaimana riset Penelitian oleh (Abdurohman 2020) yang menjelaskan riba adalah musuh utama dalam islam. Dengan adanya perbendaharaan riba yang kini sedang merambah di dunia, khususnya di Indonesia menjadikan menarik untuk dibahas oleh karenanya.

\section{Bunga Bank}

Pendapat dari hasil ijtihad yang dicanangkan oleh kalangan kebanyakan ulama sehingga telah bersepakat dari kalangan "jumhur ulama" dalam hal "Bunga Bank"yang berpendapat bahwa hukum dari "bunga bank" tidak boleh alias jelas dan tegas häram namun kalangan ulama lainnya juga ada yang berbeda pendapat seperti syaikh Abdullah yusuf ali dan juga Muhamad as'ad yang berpendapat bahwa hukum bunga yang masuk kategori dihāramkan yaitu hanyalah Ŕỉā yang berlipat ganda atau (tidak wajar). Sementara itu terkait bunga yang dilakukan (tidak berlipat ganda) maka hukumnya adalah boleh dilakukan, termasuk dalam hal ini hukum "bunga bank" yang masuk dalam kategori yang dilakukan pada zaman era disrupsi seperti sekarang ini. Perbedaan pendapat ini adalah sebuah keniscayaan, dimana meraka para ulama memiliki alasan tersendiri dalam melakukan pengambilan hukum (istinbatul ahkam) yang di latar belakangi oleh metode atau cara dalam menafsirkan yang dilakukan oleh mufassirin terhadap ayat-ayat yang membahas tentang "Ŕìbā” atau bunga bank ini. Dalam hal Penghāraman "Ŕibā" atau isitilah latinnya (usurious) dimana riba ini dimaknai sebagai pemberian pinjaman yang tidak etis (ada pemaksaan), sehingga dalam ìslam yang berdasarkan pada pertimbangan-pertimbangan dan dalil moral serta kemanusiaan, alhasil munculnya esensi dalam pelarangan "Ŕỉbā" yaitu terkait penghapusan atas segala bentuk praktik yang dilakukan dalam ber-ekonomi /bermuamalah di Indonesia yang mengakibatkan pada unsur kedzaliman yang nyata dan unsur ketidakdìlan dan juga kontribusi yang tidak seimbang, hal ini sebagaimana riset yang dilakukan oleh (Zaelani 2012). Begitupun dengan dampak yang terdapat pada bunga bank terhadap perekonomian 
khusunya di Indonesia di era disrupsi 4.0 seperti sekarang ini, adalah menjadi terhambatnya pertumbuhan ekonomi hal ini sebagaimana riset oleh (Kalsum 2014) mengapa bunga bank dilarang dikarenakan posisi konsumen atau pelanggan dan nasabah yang sedang tercekik hutang kemudian diberikan hutang tertanggung yang sifatnya fluktuatif, bukan dibantu tetapi justru malah menjadikan kesempatan dalam melakukan penambahan tagihan terhadap nasabah atau debitur tersebut.

\section{Bagi Hasil}

Bagi hasil dari sudut pandgan di kalangan Masyarakat dalam cara pandangannya terkait bagi hasil ini dalam lingkup masyarakat ekonomi syariah memerlukan toleransi dalam menghukumi ketiga hal tersebut, alhasil "bunga bank"dalam lingkup ekonomi Syariāh tidak ada (diganti dengan bagi hasil), dimana dewasa ini bagi hasil ini (ekonomi Syariah) dipandang sebagai langkah efektif dalam rangka mencegah konflik kesenjangan dalam menangani dampak pada Ekonomi dan Sosial, serta ketahanan pada lingkungan masyarakat. Profit sharing atau lebih dikenal dengan sistem bagi hasil ini adalah sebuah tata cara atau metode dalam pembagian hasil usahaantara pihak penyedia dana dengan pihak pengelola dana hal ini sebagaimana pendapat Muhammad dalam bukuunya manajemen dana bank syariah sebagaimana dikutip oleh (Marlina and Iskandar 2019: 3). Bagi hasil (Mudharabah/Profit Sharing) ini biasa kita temukan di lembaga bank syariah dimana sistem bagi hasil ini menuntut adanya win-win solution. Artinya jalinan kesepakatan dalam bagi hasil dikedepankan sesuai dengan asas saling rela (antaradhin) sal;ing meridhoi antara kedua belah pihak, tanpa adanya unsur paksaan sedikitpun. lebih lanjut Muhammad menjelaskan bahwa dalam bagi hasil ada faktor yang perlu diperhatikan yaitu faktor langsung yang berpengaruh pada nisbah yang dijanjikan dari kesepakatan bagi hasil ini, dan faktor tidak langsungnya yaitu dalam menentukan point atau item dari pendapatan yang dihasilkan dari biaya yang telah dikeluarkan dari dana utama (modal).

\section{METODE PENELITIAN}

Jenis penelitian ini adalah kategori penelitian hukum yang sifatnya normatif. Dan Metode dalam penelitian ini penulis menggunakan sumber data primer kepustakaan (buku-buku dan Jurnal ilmiah) dan sumber primernya adalah kamus-kamus hukum, internet dan lain sebagainya dalam mengkaji permasalahan terkait riba atau bunga bank, dan bagi hasi ini. Adapun 
metodologi penelitiannya adalah kualitatif. Peneliti menggunakan beberapa pendekatan ilmiah diantaranya pendekatanperundang-undangan hal ini sebagaimana penelitian oleh (Pakpahan 2020) dimana dalam riba ini dapat menghilangkan keberkan. Dalam penelitian ini peneliti menggunakan pendekatan historis guna melacak sejarah daripada riba atau bunga bank (Konvensional) dan bagi hasil (ekonomi Syariah), selain itu pendekatan komparatif atau perbandingan oleh peneliti juga gunakan guna membandingkan ekonomi konvensional dengan ekonomi syariah bagaimana pandangan kedua dual sistem ini yang ada di Indonesia. Pendekatan konseptual dalam penelitian ini juga penulis gunakan guna mengeksplorasikan bagaimana ganasnya riba ini. Sedangkan Jenis Penelitian ini adalah penelitian hukum ilmiah, yang didasarkan pada suatu cara atau metode, serta sistematika dan juga pemikiran tertentu yang mana tujuan penelitian ini guna mempelajari satu atau beberapa gejala hukum tertentu yang termasuk pada kajian riba atau bunga bank dan bagi hasil, lengkap dengan cara menganalisisnya, hal ini sebagaimana pendapat (Soekanto, 1990: 1) sebagaimana dikutip oleh (Tabroni, Ahyani, dan Permana, 2021) dalam jurnalnya gejala hukum (fenomenologi).

\section{HASIL DAN PEMBAHASAN}

\section{Pandangan Ekonomi Syariāh di Indonesia terkait "Ŕìbā"}

Riset dalam hal riba sebagaimana pendapat (Rasyid 2021) dalam bukunya berjudul "bunga bank adalah riba" beliau menjelaskan bahwa secara finansial sudah tidak ada tawar menawar lagi terkait ganasnya riba ini. Ironinya di Indonesia terkait riba ini malah justru menjadi makanan harian dimana riset terbaru oleh (Arif and Ashari 2021) bahwa penekakan riba dimasukan pada pembiayaan permodalan bagi nelayan kabupaten takalar, hal ini menyebabkan rendahnya pemasukan bagi para nelayan tersebut. Artinya riba yang dilakukan berdampak pada sektor permodalan. Selain itu Pandangan Ekonomi Syariāh di Indonesia terkait "Ŕìbā" disisi para pakar dan juga beberapa ahli hukum (Nasional) mempunyai anggapan bahwa riba merupakan musuh utama dalam perekonomian di Indonesia dikarenakan dampaknya yang sangat ganas, hal ini sebagaimana riset Penelitian oleh (Abdurohman 2020) yang menjelaskan riba adalah musuh utama dalam islam.

Dalam perspektif ekonomi Syariāh maka Pandangan Ekonomi Syariāh di Indonesia terkait "Ŕibā" yang dalam hal ini peneliti contohkan pada Perspektif hādist terkait hukum dari pada "Ŕibā" perlu dipahami bahwa fungsi dari pada hādist selain dari pada sebagai sumber 
hukum ìslam yang munqat'I (andalan) yang ke dua setelah al-Qur'an, dalam kaitannya hādist juga berfungsi sebagai al-bayan (Penjelas atau penerang), yang nilai kemanfaatnya adalah mampu memperjelas serta memperkuat dengan permasalahan apa yang telah disampaikan pada sumber utamanya yaitu alqur'ān. Seperti halnya hādist yang disampaikan oleh baginda Rasulullāh, SAW pada saat melakukan ibadah haji wādā' sebagai berikut sebagaimana pendapat (Hadi 1993, 18) dalam bukunya, yang maknanya "Ingatlah wahai kamu sekalian (manusia) akan menghadap kepada Tuhan-mu dan Dia (Allāh Swt) pasti akan menghitung (mengawasi) dan (mengganjar) apa yang kamu perbuat (amalan-mu). Allāh Swt telah melarang kamu sekalian dalam melakukan perbuatan "Ŕìbā" (penambahan harta). Oleh karenanya dalam hal hutang yang diakibatkan oleh "Ŕibā" harus sesegera mungkin ditinggalkan jauh-jauh dari kehidupan kita. Modal atau (uang pokok) kamu sekalian di dunia ini adalah sudah menjadi hak kamu sekalian. Sesekali Kamu tidak akan pernah mengalami sedikitpun penderitaan serta ketidak-ādìlan" hadits ini diriwayatkan dari (Bukhāri dan Muslim)". Hal senada sebagaimana riset oleh (Hafnizal 2018) diamana bank yang ada di Indonesia (keonvensional dan syariah) adalah sebuah perantara serta penyalur antar para pihak yang mengalami kebangkrutan/kekurangan dana untuk modal usaha, dimana manusia di dunia ini hidup dengan berbekal modal dalam konteks perekonomian di era disrupsi seperti sekarang ini. Adapun dalam hadits-hadits tentang pengharaman riba ini sudah nyata tegas hukumnya yaitu haram. Lebih lanjut (Irawati and Akramunnas 2018) dalam riset ilmiahnya bahwa pengetahuan keilmuan dilingkungan masyarakat akan ganasnya riba terdapat pada perilaku hutang piutang dengan transaksi dengan riba, oleh karenanya di era disrupsi 4.0 seperti sekarang ini perlu adanya penggemblengan yang lebih mendalam oleh para ekonom syariah yang mana tugas ini sudah menjadi kewajiban bersama dalam merangkul masyarakat akan bahanya riba tersebut.

Dalam hal riba sebagai objek yang negatif riset oleh (Sirajuddin 2018) menawarkan solusi yang jitu dalam menghadapi riba atau bunga bank bagi masyarakat diantaranya adalah dengan menjadikan pemberian kesempatan para masyarakat dengan sistem bagi hasil (karena dalam ekonomi syariah bunga itu tidak ada, yang ada hanyalah bagi hasil win-win solution. pada petani kopi yang ada di tompobulu kabupaten Bantaeng menggunakan akad appatimoro (yaitu meminjamkan uang dengan menyaurnya atau mengembalikan hutang tersebut dengan benda lain yaitu kopi). Ini sebuah ketidak adilan walaupun masyarakat tersebut meridhoinya. Akan teteapi percontohan ini tidaklah masuk pada hukum islam (ekonomi syariah) melainkan 
menjadi musuh utama dalam islam. Dalam hal lainnya seperti riset yang dicanangkan oleh (Muin 2018) bahwa arisan dengan sistem lelang dimana unsur gharar muncul dalam model arisan ini yang mana pada pelaksanaanya transaksi muamalah seperti ini dilarang dan ini masuk pada kategori riba dan maisir (mengandung kerugian) yang nyata pada masyarakat Luwu Utara desa Pomacang.Pendapat lainnya sebagaimana dikutip dari jurnal karya (Ahyani dan Muharir 2020) dan (Ahyani, Permana, dan Abduloh 2020) mengenai “Ŕibā” juga hāram hukumnya dikarenakan mempunyai unsur yang merugikan dan hal ini tidak sesuai dengan islam (ekonomi syariah). Dengan pembahasan diatas terkait pandangan bahwa riba secara tegas keharamannya maka peneliti dapat memberikan kesimpulan bahwa tinjauan dari berbagai literatur ilmiah diatas terkait eksistensi riba bahwa sangat ganas dan jahat dalam hal merusak perekonomian di Indonesia, baik ekonomi konvensional maupun ekonomi syariah secara lebih mendalam masuk pada sektor akad atau transaksi yang tanpa disadari oleh kita sebagai masayarakat ekonomi syariah. Adapun solusi utama dari riba ini yang notabane menajdi musuh utama adalah dapat diatasi dengan sesegera mungkin mempublikasikan serta mensosialisasikan terkait riba ini guna memberikan pemahaman kepada masyarakat baik non muslim terlebih bagi yang beragama islam.

\section{Pandangan Ekonomi Syariāh di Indonesia tentang "Bunga Bank"}

Dalam hal ini dari sudut pandang kacamata ekonomi syariah terait hukum daripada "bunga bank"adalah termasuk tergolomg pada"rìbā”, sehingga terkait"bunga bank ini juga dihāramkan dalam ajaran (ekonomi syariah) ìslam. Sehingga Pandangan dari disiplin ilmu Ekonomi Syariāh di Indonesia tentang "Bunga Bank" adalah secara tegas tergolong "Ŕìbā" yang ada di Indonesia di zaman yang serba digital seperti sekarang ini khususnya salah satunya dapat sering terjadi pada transaksi pinjam meminjam yang sifatnya konsumtif (kebutuhan harian) atau hajjiyah maupun pinjaman yang bersifat produktif (permodalan). Dan bunga bank ini pada hakikatnya "Ŕibā" dalam konteks "bunga bank" yang memberatkan bagi pihak si peminjam. Terkait permasalahan "Ŕibā”yang muncul dan unik untuk dibahas lebih lanjut adalah jika riba ditinjau dari aspek hukum islam dan hukum nasional serta dengan anaslisi hasil ijtihad (penafsiran para mufassir) khusunya mufassir di Indonesia yang terus mengalami perbedaan atau perdebatan akan hal riba /bunga bank ini, alhasil pandangan para mufassir akan status hukumnya adalah tegas jelas unsur (kehāramannya). Adapun jika "bunga bank" di 
tinjauan dari aspek hukum ìslam dan dihubungkan dengan konteks dampak terhadap perekonomian di Indonesia di era seperti sekarang (masa pandemi misalnya) tentu menjadikan tambah peliknya konseposi bunga bank ini. Dengan demikian setelah dianalisis dari pada dampak (bunga bank) terhadap perekonomian di Indonesia di era kekinian ini, baik yang dikemukan oleh para pakar ekonomi ìslam, maupun para mufassir maka alhasil para mufasir dan juga para ekonom muslim lainnya telah sepakat tentang status dari bunga bank ini yaitu termasuk riba. Begitupun dari letak perbedaan pendapat yang dicanangkan oleh para alim ulama atau fuqāha (ahli fiqh) dimana fikih ini selalu berkembang sesuai dengan tuntutan zaman, maka dalam pandangan status hukum dari pada“bunga bank" adalah masuk kategori riba, serta dalam ranah menganalisa terhadap dampaknya pun seudah dijelaskan diatas, bahwa yang ditimbulkan bunga bank dalam kaitannya hasil ijtihad para ulama, maka oleh hukum ìslam dampak yang dihasil kan dari bunga bank ini terhadap perekonomian di Indonesia baik pada tingkat mikro ataupun makro akan menjadi pertimbangan bagi para nasabah/konsumen yang ada di Indonesia untuk melakukan praktik bunga bank ini. Hal ini senada dengan pendapat (kalsum, 2014) dimana bunga bank dapat memperlambat lajunya perekonomian. Dimana pelarangan ini dikarenakan posisi konsumen atau pelanggan dan nasabah yang sedang tercekik hutang kemudian diberikan hutang tertanggung yang sifatnya fluktuatif, bukan dibantu tetapi justru malah menjadikan kesempatan dalam melakukan penambahan tagihan terhadap nasabah atau debitur tersebut.

Pendapat atau hasil ijtihad oleh kalangan kebanyakan telah bersepakat dari kalangan "jumhur ulama" dalam hal "Bunga Bank"yang berpendapat bahwa hukum dari "bunga bank" tidak boleh alias jelas dan tegas hāram namun kalangan ulama lainnya juga ada yang berbeda pendapat seperti syaikh Abdullah yusuf ali dan juga Muhamad as'ad yang berpendapat bahwa hukum bunga yang masuk kategori dihāramkan yaitu hanyalah Ŕibā yang berlipat ganda atau (tidak wajar). Sementara itu terkait bunga yang dilakukan (tidak berlipat ganda) maka hukumnya adalah boleh dilakukan, termasuk dalam hal ini hukum "bunga bank" yang masuk dalam kategori yang dilakukan pada zaman era disrupsi seperti sekarang ini. Perbedaan pendapat ini adalah sebuah keniscayaan, dimana meraka para ulama memiliki alasan tersendiri dalam melakukan pengambilan hukum (istinbatul ahkam) yang di latar belakangi oleh metode atau cara dalam menafsirkan yang dilakukan oleh mufassirin terhadap ayat-ayat yang membahas tentang "Ŕibā" atau bunga bank ini. Dalam hal Penghāraman "Ŕìbā" atau isitilah 
latinnya (usurious) dimana riba ini dimaknai sebagai pemberian pinjaman yang tidak etis (ada pemaksaan), sehingga dalam ìslam yang berdasarkan pada pertimbangan-pertimbangan dan dalil moral serta kemanusiaan, alhasil munculnya esensi dalam pelarangan "Ŕìbā" yaitu terkait penghapusan atas segala bentuk praktik yang dilakukan dalam ber-ekonomi /bermuamalah di Indonesia yang mengakibatkan pada unsur kedzaliman yang nyata dan unsur ketidakdìlan dan juga kontribusi yang tidak seimbang, hal ini sebagaimana riset yang dilakukan oleh (Zaelani 2012). Begitupun dengan dampak yang terdapat pada bunga bank terhadap perekonomian khusunya di Indonesia di era disrupsi 4.0 seperti sekarang ini, adalah menjadi terhambatnya pertumbuhan ekonomi hal ini sebagaimana riset oleh (Kalsum 2014) mengapa bunga bank dilarang dikarenakan posisi konsumen atau pelanggan dan nasabah yang sedang tercekik hutang kemudian diberikan hutang tertanggung yang sifatnya fluktuatif, bukan dibantu tetapi justru malah menjadikan kesempatan dalam melakukan penambahan tagihan terhadap nasabah atau debitur tersebut.

Riset oleh (Ardiansyah et al. 2019) membuktikan bahwa dalam pembiayaan murabahah yang banyak diminatai pada bank syariah di Indonesia salah satunya dipengaruhi oleh inflasi dan oleh pihak Bank Indonesia, dimana manajemen yang ada pada bank syariah di Indonesia di era seperti sekarang ini (disrupsi 4.0) perlu meningkatkan kualitas layanannya dan juga sesegera mungkin mensosialisasikan terkait pembiayaan pendanaan yang unggul dari pada bank syariah yang notabene berbasis syariah islami kepada kalangan masyarakat atau calon konsumen. Hal senada juga terjadi pada nasabah bank BNI KCU Universitas Diponegoro semarang dimana kualitas pelayanannya berpengaruh pada pendapatan usaha dengan mengambil kredit yang ada pada bank tersebut(Chrisanti and Saryadi 2017). Dalam menghadapi tergerus dan goncangan ekonomi di tengah pandemi seperti sekarang ini dalam mempertahankan suku bunga yang dilakukan oleh Bank Indonesia guna mentralisir inflasi yang akan terus naik sehingga perlu adanya upaya menyeluruh dalam perbaikan perekonomian di indonesia di masa pandemi seperti sekarang ini. alhasil bunga bank yang secara umum adalah boleh dilakukan, tetapi ditinjau dari ekonomi syariah ditengah pandemi seperti sekarang ini adalah perlu dilakukan guna menetralisir goncangan ekonomi moneter dari pemerintah. Hal ini sebagaimana riset ilmiah oleh (Amin 2020) bahwa stabilitas makro ekonomi dimana bukti stabilitas ini dapat diketahui melalui lajunya inflasi dan melihat pertumbuhan ekonomi di suatu negara. 


\section{Perspektif Ekonomi Syariāh di Indonesia terkait "Bagi Hasil"}

Pandangan Ekonomi Syariah di Indonesia era disrupsi 4.0 terkait bagi hasil seperti sekarang ini pandangan oleh (Mokorowu, Rotinsulu, and Engka 2021) model bagi hasil dapat menumbuhkembangkan dalam tingkat perekonomian dibeberapa wilayah di Indonesia yang dalam hal ini sangat membantu dalam peningkatan perekonomian di minasaha tenggara dengan pendapatan asli daerah atau (PAD) menjadikan pemerataan keuangan antar daerah setempat. Hal senada sebagaimana dalam penelitian ini kaitannya Perspektif Ekonomi Syariāh di Indonesia yang membahas Bagi Hasil dalam riset ilmiah (Marlina dan Iskandar 2019) yang ada pada lembaga bank yang ada di Provinsi Jawa Barat yaitu tepatnya di bank BJB Banten Syariāh dengan posisi Kantor cabang pembantu di wilayah Singaparna Tasikmalaya Jawa barat. Hal senada apa yang disampaikan oleh (Williantara and Budiasih 2016) dalam jurnalnya bahwa dalam bertujuan meningkatkan Indeks pembangunan manusia perlu dilakukan sistem murabahah yang banyak diminati oleh masyarakat baik muslim maupun non muslim ini.

Riset ilmiah oleh (Williantara and Budiasih 2016) ini dijelaskan bahwa bagi hasil dapat menjadikan indeks pembangungan manusia, berbeda dengan riba atau bunga bank pada perbankan konvesional yang justru merugikan perekonomian di Indonesia, dimana nilai prestasi dalam hal pembangunan ini terdapat dan terlihat dari pada realisasi anggaran yang diberikan. Terkait strategi atau metode cara memasarkan program bagi hasil (Rusandry 2021) Bank syariah menawarkan aktivitas dalam pembiayaan yang mana model pembiayaan ini dapat mempengaruhi. Salah satu bukti kongkritnya adalah dengan pemberian wakaf uang dalam menyalurkan dana zakat yang tentunya dengan profesionalitas yang tinggi dengan menggunakan One sistem bukan dual sistem (konvensional dan syariah) melainkan dengan sistem pembiayaan dengan cara bagi hasil (bisa dengan prinsip Mudharabah), atau pun dengan prinsip Musyarakah. Dalam peluang yang dimiliki oleh ekonomi syariah di Indoensia di era disrupsi seperti sekarang ini perbankan syariah menawarkan sebuah gagasan dalam hal pembiayaan seperti halnya penelitian yang dilakukan oleh (Primadhita, Primatami, and Budiningsih 2021) bahwa skema profit sharing dan juga revenue sharing ini merupakan kredit yang dapat mempengaruhi terhadap pembiayaan bagi hasil, alhasil pentasarufan pembiayaan yang ada perbankan syariah di indoneisa dengan basis sistem bagi hasil ini menjadikan perekonomian di Indonesia saat ini (era disrupsi 4.0) menjadi meningkat. 
Selain itu (Fajriah and Jumady 2021) dalam riset ilmiahnya menerangkan bahwa pembiayaan terhadap deposit juga mempengaruhi pada nilai profitabilitas yang tinggi dimana bak syariah yang jumlahnya 14 bank dapat meningkatkan nilai pembiayaan pada bank tersebut, alhasil dengan adanya peningkatan pembiayaan ini yang merupakan kebutuhan dari bank syariah itus sendiri ada beberapa faktor diantaranya adanya faktor makroekonomi di tingkat inflasi dan nilai tukar. Ketika individu atau bahkan sekelompok tertentuyang memegang hartanya suntuk dijadikan ebagai modal usaha dalam "bagi hasil", lalu menggunakan harta tersebut dalam transaksi yang tidak secara langsung atau tidak tunai dan pemilik harta tidak menyuruh dan tidak pula melarang-nya maka ketika terjadi sessuatu pada harta tersebut, para pihak pengelola harus mengganti rugi kepada pemilik modal. Inilah bentuk keadilan daripada sistem bagi hasil dari sudut ekonomi syariah di era disrupsi seperti sekarang ini.

Artinya dalam hal ini terkait pembagian dana (bagi hasil) terhadap pengelola atau mudhārib-nya berhak atas pendapatan-pendapatan yang dihasilkan oleh badan usaha terkait, tanpa adanya durasi waktu tunggu dengan pengurangan-pengurangan pada pembiayaanpembiayaan yang akan dikeluarkan oleh pihak badan usaha tersebut, selain itu dalam pengelolaan dana yang diamanatkan oleh pihak pengelola tertentu ini, disatu sisi dalam pelaksanaan Revenue Sharing yang dijadikan jalan alternatif ini bertentangan dengan prinsip "bagi hasil" yang ada pada ekonomi syariah, hal ini dikarenakan dalam prinsip "bagi hasil" pada ekonomi syariah yang seharusnya investorlah yang bertanggung jawab atas modal /dana yang diamanahkan, maka dengan demikian alhasil bagi hasil memiliki sumbangsih dalam kaitannya pengelolaan dana tersebut, bahkan jika terjadi suatu ancaman/kerugian dalam suatu kegiatan usaha yang berbasis bagi hasil maka Sāhibuul maāl atau insvestor harus ikut serta dalam menanggung atas kerugian yang didapatkan. Bagi hasil/Murabahah/ Revenue Sharing adalah sebuah alternatif yang dapat diambil dalam menghadapi kesulitan permodalan, terlilitnya hutang tertanggung dengan metode ta'awun (tolong menolong) ini untuk dijadikan sebuah pemahaman ilmu ekonomi syariah kedepannya.

Dalam hal ini contoh misalnya pola bagi hasil dengan akan mudhārābāh (perjanjian) dalam usaha di BUMP yang ada di PondokPesantren Luqmaniyah Kota Yogyakarta yang terdiri dari beberapa BU (badan usaha) yang tidak ke-semuanya itu sama dalam hal penerapan pola bagi hasil usahanya. Ada beberapa badan usaha di lingkungan BUMP yang telah menerapkan pola "bagi hasil" sebelum nantinya akan dikurangi biaya operasionalnya yang diambil dari laba 
usaha tersebut. Selain itu ada juga yang menerapkan pola "bagi hasil" dengan usaha profit sharing ini dengan pola bagi hasil-nya ini, dilakukan setelah dikurangi oleh biaya operasional dari pihak BU (badan usaha) tersebut yang melakukan perjanjian secra sah. Dalam perspektif hukum bisnis Syariāh terkait pola "bagi hasil" semacam ini adalah akad mudarabah-nya sangat sesuai dengan prinsip Syariāh (hukum islam). Hal ini terlihat dari telah terpenuhinnya syarat serta rukun dalam akad tersebut, dan juga dalam hal "kesesuaian dengan prinsip-prinsip hukum ìslam" tentang pengaturan atau regulasi ekonomi (muamālāh dan etika bisnis Syariāh). Praktik mudharābāh/perjanjian ini yang dilakukan pada BUMP Yogyakarta ini telah dilaksanakan atas dasar absahnya kesepaktan kerjasama tersebut. dan alhasil pola bagi hasilnya ini telah sesuai dengan kesepakataan awal bersama yaitu antara pihak pengelola dan shāhibul māl yang menhindari dari unsur Ŕibā dan hal-hal yang samar atau belum jelas status untung ruginya (Gharar) dalam akad tersebut (Putra 2018). Riset ilmiah lainnya dalam hal ini (bagi hasil) yang dicanangkan dalam penelitian ilmiah oleh (Ni'mah dan Yuliana 2020) dimana ditemukan bahwa terdapat transaksi $e$-wallet (dompet elektronik) dengan kesesuaian dalam memenuhi prinsip andal dan aman yang bertujuan menjaga kekayaan serta manfaat aplikasi tersebut. Tetapi $e$-wallet ini dianggap tidak sesuai dengan hifzul $m \bar{a} l$ (pemeliharaan harta benda) hal ini dikarenakan aplikasi elektrik ini (e-wallet) ketika digunakan masih dalam kondisi yang terbilang rawan (kurang aman) terhadap kesempatan dalam melakukan kejahatan teknologi (dalam transaksi elektronik), terlebih di era digital seperti sekarang ini, tetapi aplikasi e-wallet ini perlu menawarkan dengan kelebihan dalam hal pemanfaatannya yang dibuktikan dengan cara (setiap orang boleh dengan mudah memiliki lebih dari satu akun e-wallet). Artinya disinilah keadaan rawan (kurang aman) dalam pemanfaatan aplikasi berbasis elektronik ini (mudah dibobol oleh hacker yang canggih).

Perspektif Ekonomi Syariāh terkait "Prinsip Kerja", Pemahaman tentang Ekonomi syariah dalam "prinsip kerja" dalam kaitannya hal ini diteegaskan bahwa tentang kerja dan kompensasi yang dilakukan dari kerja itu sendiri yang telah dikerjakan. Pada prinsip kerja disini juga menentukan jikaseseorang harus professional dengan kategori pekerjaan yang hendakdikerjakan. Sehingga dalam peneltuannya prinsip kerja dalam islam harus ada perhitungan misalnya terkait "jam kerja" yang jelas dan harus pula "kategori” yang spesifikasi bagi para pekerja atau disesuaikan dengan kompetensi dan job description-nya. Kemudian mengenai upah juga harus berimbang, dan dari seetiap speesifikasi itu harus didasarkan pulaatas 
"upah minimum" dan disesuaikan dengan gajiminimum yang ditetapklan oleh pemerintah, khususnya pemerintah Indonesia di wilayah setempat. Dalam penelitian yang dicanangkan oleh (Marlina 2020) dalam jurnalnya bahwa prinsip kerja selain didukung oleh pihak pemerintah, dalam kaitannya berkembangnya perbankan Syariāh juga adanya dukungan dari pada kualitas perbankan itu sendiri, juga terkait pelayanan serta āl'ādl. Namun pada Bank Syariāh hanya menggunakan system "bagi hasil" bukan dengan bunga. Sehingga prinsip kerja perspektif ekonomi Syariāh di Indonesia sudah sesuai dengan prinsip syariat ìslam artinya ada prinsip keseimbangan dan keādìlan dalam prinsip kerja tersebut. Sedangkan Perspektif Ekonomi Syariāh terkait "Prinsip Keseimbangan". Guna menjadikan darurat (Dharuriyat), kebutuhan (tahshiniyah) dimana kebutuhan menjadikan tetap eksisnya kebutuhan (tidak fakir) dalam ekonomi syariah tidak menimbulkan kesulitan atau (mendzalimi diri sendiri) dan juga dalam hal keseimbangan perlu hajjiyah (kebutuhan sebagai pelengkap) yang dijadikan dasar dalam prinsip kesimbangan, hal ini sebagaimana pendapat (Ahyani and Slamet 2021) boleh melakukan wanprestasi dimana hal ini dibutuhkan menuju prinsip keseimbagan hidup dalam transaksi (bermu'amalah) dari sudut pandang ekonomi syariah dengan alasan yang kuat yaitu menuju ke arah seimbang dalam hidup, dimana Islam mengajarkan jadilah orang kaya yang produktif (muntij) bukan menjadi seorang Penonton/Peminta/pemboros/komsumtif saja (mustahlik).

\section{Dampak Ŕìbā, Bunga Bank, Bagi hasil terhadap Perekonomian di Indonesia}

Negara Indonesia merupakan salah satu Negara yang terbesar yang menganut agama ìslam. Indonesia memiliki kebijakan Dual Banking System, dimana sistem yang menggunakan Bank Syariāh yang diterapkan baru mendapatkan ijin resmi dalam beroperasi pada tanggal 01 mei tahun 1992 atau bertepatan dengan tanggal 27 Syawal 1412 H, yakni dengan di dirikan-nya Bank Muāmalāt Indonesia disingkat BMI yang digagas oleh pemerintah dalam hal ini MUI (Majelis Ulamā Indonesia). Dengan telah terjadinya krisis yang melanda dalam dekade tahun terakhir yaitu diawali di tahun 1997 adalah sebuah ujian untuk kali pertama dalam sistem keuangan Syariāh di Indonesia. Hadirnya krisis yang bermula dari krisis nilai tukar atau Baht di negara Thailand yang mana telah mengalami fluktuasi yang menjadikan krisis ekonomi di Negeri Jiran tersebut, kemudian berlanjut lagi pada krisis sosial juga melanda, bahkan sampai pada puncaknya krisis politik. Alhāsil krisis yang melanda sampai ke negara kita ini 
(Indonesia), namun kini Indonesia mampu melumpuhkan krisi tersbut dengan cara masuk pada seluruh lini kehidupan bangsa Indonesia dengan bersama-sama menghadapi bersama (bersatu) dalam menghadapi krisis yang sudah berjalan di tahun 1997, yang mana selama kurang lebih 6 bulan krisis tersebut menjadikan semakin menburuk dalam jangka waktu yang cukup relatif cepat. Sehingga tepatnya di tahun 1997, pada tanggal 1 Nopember pihak pemerintah Indonesia mencabut ijin terhadap (16 Bank) dengan alasan tidak mampu lagi menjalankan tugas operasional-nya dengan baik dan efesien serta kondusif lagi. Sementara itu peranan dan eksistensi dari Bank Muāmalat Indonesia (BMI) tidak lagi mampu beroperasi kembali oleh karena hal tersebut, namun dengan hal tersebut krisis ini dapat teratasi, dimana BMI juga lolos dalam gejolaknya krisis tersebut. Hal ini merupakan suatu gejolak /cobaan yang pada dasarnya bank yang menjalankan atas sistem operasional-nya yang menggunakan "bunga" dengan mengalami kerugian yang besar sementara bank yang mengoperasikan sistem bagi hasil secara Islami/Syariāh tidak demikian adanya (Mashuri 2017). Hal senada sebagaimana riset ilmiah yang dilakukan oleh (Toluhula 2008) dijelaskan bahwa terdapat dampak negatif dalam pengembangan dunia perbankan syariah di Indonesia seperti sekarang ini (artinya bank syariah tidak dapat berdiri sendiri) dan ini artinya peluang terkontaminasi oleh bank konvensional sangat dimungkinkan. Begitupun (Rahmatika 2014) dalam artikel ilmiahnya bahwa banyaknya dana yang menganggur (idle fund) dapat diatasi oleh bank (konvensional dan Syariah) yaitu dengan cara mengembangkan pendanaan/permodalan (funding) dan juga pinjaman (lending).

Era disrupsi seperti yang terjadi di zaman sekarang ini potensi ekonomi syariah di jawa barat diperlukan guna menunjang ketahanan ekonomi yang menyeluruh, para peneliti seperti peneliti (Ahyani, Muharir, and Ulya 2021) menjelaskan dalam risetnya bahwa di kota banjar jawa barat dalam hal wisata halal yang selalu mengalami perkembangan yang disebabkan tuntutan zaman (disrupsi 4.0) seperti sekarang ini perlu lebelisasi produk terlebih dahulu, dengan tetap memperhatikan situasi dan kondisi pada linkungan yang mendukung. Lebih lanjut (Hisam et al. 2021) dalam temuan risetnya bahwa di kabupaten ciamis, Cilacap, dan juga Kabupaten banyumas terkait labelisasi produk pangan mengalami dukungan dari pihak pemerintah setempat dengan mengandalkan kehalalan pada jenis makanan. Oleh karenanya bagi hasil yang dicanangkan oleh ekonomi syariah di era disrupsi seperti sekarang ini juga perlu menjalin singkronisasi konsep, begitupun pada riba dan bunga bank dimana dapat memberi dampak pada ekonomi di Indonesia yaitu dampak ketahanan ekonomi yang unggul dan bijak. 
Begitupun terkait pelaporan dalam perbankan syariah atau non bank, dimana (Nazhifah, Wisandani, dan Marlina 2020) menjelaskan bahwa sebagai dasar laporan keuangan yang eligible (masuk kualifikasi syariah) perlu adanya singkronisasi pada entitas syariah terhadap PSAK 101 dalam hal penyajian serta penyusunan laporan keuangan, dengan hal ini keseimbangan dalam perekonomian di indonesia akan selalu terjaga dengan baik.

\section{KESIMPULAN}

Berdasarkan latar belakang dan permasalahan diatas peneliti menyimpulkan dari sudut pandang ekonomi syariah terkait bagi hasil, riba dan juga bunga bank memberi dampak yang baik bagi perekonomian di Indonesia, dimana sistem bagi hasil dapat membantu masyarakat dalam hal ketahanan sosial, serta mengatasi kesenjangan sosial (menjadikan tahsin/ kemaslahatan ummat). Sehingga di kalangan Masyarakat dalam cara pandangannya terkait riba, bunga bank dan juga bagi hasil ini dalam lingkup masyarakat ekonomi syariah memerlukan toleransi dalam menghukumi ketiga hal tersebut, alhasil "bunga bank"dalam lingkup ekonomi Syariāh tidak ada (diganti dengan bagi hasil), dimana dewasa ini bagi hasil ini (ekonomi Syariah) dipandang sebagai langkah efektif dalam rangka mencegah konflik kesenjangan dalam menangani dampak pada Ekonomi dan Sosial, serta ketahanan pada lingkungan masyarakat.

\section{REFERENSI}

Amin, Eka Mulia Nurul al. 2020. "Kebijakan Pemerintah Mempertahankan BI 7-Day Reverse Repo Rate Sebesar 4,50\%." Iqtishaduna: Jurnal Ilmiah Ekonomi Kita 9 (2) : 125-35. Doi: 10.46367/iqtishaduna.v9i2.238.

Aravik, Havis, Achmad Irwan Hamzani, and Nur Khasanah. 2021. "Dari Konsep Ekonomi Islam Sampai Urgensi Pelarangan Riba; Sebuah Tawaran Ekonomi Islam Timur Kuran.” Islamic Banking : Jurnal Pemikiran dan Pengembangan Perbankan Syariah 6 (2) : 215-32. Doi: 10.36908/isbank.v6i2.177.

Ardiansyah, Ardiansyah, Hadira Thumaninah Jibril, David Kaluge, and Kasnaeny Karim. 2019. "Permintaan Pembiayaan Murabahah Berdasarkan Tingkat Inflasi dan Suku Bunga BI Rate pada Bank Syariah di Indonesia.” Bisma: Jurnal Bisnis dan Manajemen 13 (3) : 172-80. Doi: 10.19184/bisma.v13i.11242. 
Arif, Hermita, and Muhammad Ashari. 2021. "Investigasi Praktik Riba pada Pembiayaan kepada Nelayan: Studi Kasus pada Kabupaten Takalar.” Jurnal Ekonomi Syariah Teori dan Terapan 8 (1) : 108-15. Doi: 10.20473/vol8iss20211pp108-115.

Abdurohman, Dede. 2020. “Kontrak/Akad dalam Keuangan Syariah.” Ecobankers : Journal of Economy and Banking 1 (1): 39-58.

Http://journal.bungabangsacirebon.ac.id/index.php/ecobankers/article/view/72.

Ahyani, Hisyam, dan Elah Nurhasanah. 2020. "Peran Strategi Politik Ìslam terhadap Perekonomian di Indonesia.” Mutāwāsith: Jurnal Hukum İslam 3 (1): 18-43. https://doi.org/10.47971/mjhi.v3i1.185.

Ahyani, Hisam, dan Muharir. 2020. "Dialog Pemikiran Tentang Norma "ŕìbā”, Bunga Bank, dan "Bagi Hasil” di Era Revolusi Industri 4.0.” Eksisbank (Ekonomi Syariāh dan Bisnis Perbankan) 4 (2): 232-54. Https://doi.org/10.37726/ee.v4i2.140.

Chrisanti, Yulita Martha, and Saryadi Saryadi. 2017. "Pengaruh Tingkat Suku Bunga, Kualitas Pelayanan dan Pendapatan Usaha terhadap Keputusan Pengambilan Kredit (Studi Kasus pada Nasabah BNI KCU UNDIP Semarang).” Jurnal Ilmu Administrasi Bisnis 6 (3) : 666-75.

Fajriah, Yana, and Edy Jumady. 2021. "Pembiayaan Bagi Hasil dan Financing to Deposit Ratio (FDR) terhadap Profitabilitas Bank Umum Syariah di Indonesia.” Islamic Banking : Jurnal Pemikiran dan Pengembangan Perbankan Syariah 6 (2) : 233-48. Doi: 10.36908/isbank.v6i2.200.

Ghofur, Abdul. 2016. “Konsep Riba dalam Al-qur'an.” Economica: Jurnal Ekonomi Islam 7 (1) : 1-26. Doi: 10.21580/economica.2016.7.1.1030. 
Hafnizal, Veri Mei. 2018. "Bunga Bank (Riba) dalam Pandangan Hukum Islam.” At-tasyri': Jurnal Ilmiah Prodi Muamalah 47-60.

Ahyani, H., Mahfud, M., Waluyo, R., Ulya, W., \& Muharir. (2021). The Potential of Halal Food on the Economy of The Community in the Era of Industrial Revolution 4.0. Indonesia Journal of Halal, 3 (2), 112-128. Https://doi.org/10.14710/halal.v3i2.10244

Irawati, Irawati, and Akramunnas Akramunnas. 2018. "Pengetahuan Masyarakat tentang Riba terhadap Perilaku Utang Piutang di Kecamatan Anreapi Polewali Mandar.” Laa Maisyir : Jurnal Ekonomi Islam 5 (2). Doi: 10.24252/lamaisyir.v5i2.7275.

Kalsum, Ummi. 2014. "Ŕibā" dan "Bunga Bank”dalam İslam (Analisis Hukum dan Dampaknya terhadap Perekonomian Umat)." Al-'adl $7 \quad$ (2): 97-83. Https://doi.org/10.31332/aladl.v7i2.220.

Mokorowu, Lian Arke, Debby CH Rotinsulu, and Daisy S. M. Engka. 2021. "Pengaruh Pendapatan Asli Daerah (PAD), Dana Bagi Hasil (DBH, Dana Alokasi Umum (DAU) dan Dana Alokasi Khusus (DAK) terhadap Pertumbuhan Ekonomi Kabupaten Minahasa Tenggara.” Jurnal Pembangunan Ekonomi dan Keuangan Daerah 20 (8) : 18 31. Doi: 10.35794/jpekd.31645.20.8.2021.

Muin, Rahmawati. 2018. "Perilaku Masyarakat terhadap Pelaksanaan Arisan Lelang dalam Perspektif Ekonomi Islam (Studi Kasus Masyarakat Desa Paomacang Luwu Utara).” Laa Maisyir : Jurnal Ekonomi Islam 5 (1). Doi: 10.24252/lamaisyir.v5i1.4956.

Mashuri. 2017. Analisiis Dampak “Bunga Bank”(“'́ìbā”) bagi Perekonomian Negara. Iqtishāāduna: Jurnal Ilmiah Ekonomi Kita, 98-

107.https://ejournal.stiesyariāhbengkalis.ac.id/index.php/iqtishaduna/article/view/97. 
Marlina, Lina. 2020. “Faktor-Faktor yang Mempengaruhi Minat Non Muslim Menjadi Nasabah Bank Syariāh di Tasikmalaya.” Eqien: Jurnal Ekonomi dan Bisnis 7 (1): 33-40. Https://doi.org/10.34308/eqien.v7i1.110.

Marlina, Lina, dan Jajang Iskandar. 2019. "Pengaruh "Bagi Hasil” dan Pendapatan Per Kapita terhadap Peningkatan Dana Pihak Ketiga.” Jurnal Ekonomi Syariāh 4 (1). Https://doi.org/10.37058/jes.v4i1.798.

Ni'mah, Rohmatun, dan Indah Yuliana. 2020. “E-Wallet: Sistem Pembayaran dengan Prinsip Hifzul Māl.” Jurnal Ekonomi Syariāh $5 \quad$ (2): 52-66. Https://doi.org/10.37058/jes.v5i2.2016.

Nazhifah, Naurah, Iwan Wisandani, dan Lina Marlina. 2020. “Analisis Implementasi PSAK 101 pada Laporan Keuangan di KSPPS BMT Al-Bina Tasikmalaya.” Jurnal Ekonomi Syaariāh 5 (1): 42-58. Https://doi.org/10.37058/jes.v5i1.1577.

Pakpahan, Elpianti Sahara. 2020. "Pengharaman Riba dalam Islam.” Jurnal Ilmiah Al-Hadi 4 (2) : 865-76.

Primadhita, Yuridistya, Anggraita Primatami, and Susilowati Budiningsih. 2021. "Determinan Pembiayaan Bagi Hasil pada Perbankan Syariah:” Ekomabis: Jurnal Ekonomi Manajemen Bisnis 2 (01) : 1-10. Doi: 10.37366/ekomabis.v2i01.149.

Permana, Iwan, dan Gina Sakinah. 2020. "Peran Wakāf sebagai İslamic Social Finance dalam Pemberdayaan Pondok Pesantren Tahfidz Al Maa Parung Bogor.” Jurnal Ekonomi Syariāh 5 (2): 67-76. Https://doi.org/10.37058/jes.v5i2.1991.

Putra, Yahya Hidayat. 2018. “Tinjauan Hukum Ìslam terhadap Pola "Bagi Hasil” (Mudarabah) pada BUMP (Studi Kasus di Pondok Pesantren Al-Luqmaniyyah Umbulharjo 
Yogyakarta)." Al-Māzāhib : Jurnal Pemikiran Hukumm 5 (2). Http://ejournal.uinsuka.ac.id/syariāh/almazahib/article/view/1425.

Rahmatika, Arivatu Ni’mati. 2014. "Dual Banking System di Indonesia.” At-Tahdzib: Jurnal Studi Islam dan Muamalah 2 (2) : 133-47.

Rasyid, Rasyidin. 2021. "Bunga Bank adalah Riba |." Retrieved February 11, 2021 (https://repository.uia.ac.id/2021/01/12/bunga-bank-adalah-riba/).

Rusandry, Rusandry. 2021. "Strategi Peningkatan Pembiayaan Bagi Hasil pada Bank Syariah di Indonesia.” Jurnal Ilmiah Wahana Pendidikan 7 (1) :102-14. Doi: 10.5281/zenodo.4486304.

Sirajuddin, Sirajuddin. 2018. 'Sistem Appattimoro' pada Petani di Kelurahan Campaga Kecamatan Tompobulu Kabupaten Bantaeng.” Laa Maisyir : Jurnal Ekonomi Islam 4 (2). Doi: 10.24252/lamaisyir.v4i2.4418.

Syarif, Mujar Ibnu. 2011. "Konsep Riba dalam Alquran dan Literatur Fikih.” Al-Iqtishad: Jurnal Ilmu Ekonomi Syariah 3 (2) : 293-312-312. Doi: 10.15408/aiq.v3i2.2527.

Toluhula, Uki Setiawan. 2008. “Dual Banking System.” Universitas Gadjah Mada. Williantara, Gede Ferdi, and I. Gusti Ayu Nyoman Budiasih. 2016. "Pengaruh Pendapatan Asli Daerah, Dana Alokasi Umum, Dana Alokasi Khusus, dan Dana Bagi Hasil pada Indeks Pembangunan Manusia.” E-jurnal Akuntansi 16 (3) : 2044-70.

Yulianti, Rahmani Timorita. 2016. "Riba dalam Perspektif Ekonomi Islam.” Millah: Jurnal Studi Agama 1 (2) : 51-70.

Tabroni, Imam, Hisam Ahyani, dan Dian Permana. 2021. "Philosophical Review Of Materialism and Idealism Limits Of Wedding Age In Indonesia; Study of Article 7 Paragraph (1) of Law 16 of 2019 jo. Law 1 of 1974 concerning marriage | muttaqien: 
indonesian journal of Multidiciplinary Islamic Studies" 2 no 01 (2021). Http://ejurnal.staimuttaqien.ac.id/index.php/mtq/article/view/111

Zaelani, Abdul Qodir. 2012. "Bunga Bank dalam Perspektif Sosio-Ekonomi dan Ushul Fiqh (Studi atas Pemikiran M. Umer Chapra).” ASAS 4(2). Doi: 10.24042/asas.v4i2.1678.

Ahyani, Hisam, Dian Permana, dan Agus Yosep Abduloh. 2020. "Dialog Pemikiran tentang Norma "Ŕibā", Bunga Bank, dan "Bagi Hasil” di Kalangan Ulama.” Kordinat: Jurnal Komunikasi antar Perguruan Tinggi Agama İslam 19 (2): 247-264-264. Https://doi.org/10.15408/kordinat.v19i2.18899.

Ahyani, Hisam, and Memet Slamet. 2021. "Proses Jurnal At-Tanwir Umgo 27 Jan 2021 Tinjauan Hukum Islam terhadap Wanprestasi Perjanjian Kerja Dosen Tetap di PTKS Jawa Barat."

Ahyani, Hisam, Muharir Muharir, and Widadatul Ulya. 2021. "Potensi Wisata Halal Kota Banjar, Jawa Barat di Era Revolusi Industri 4.0.” Tornare: Journal of Sustainable and Research 3 (1):4-12. Doi: 10.24198/tornare.v3i1.31511. 